\title{
LOPES, José Rogério (Org.). Viagens de Cabo Verde: ensaios de antropologia visual e outros ensaios. Porto Alegre: Cirkula, 2015. $178 \mathrm{p}$.
}

Raimunda Maria Rodrigues Santos*

*Instituto Federal de Educação, Ciência e Tecnologia de Roraima Boa Vista, RR, Brasil

raimundarodrigues@ifrr.edu.br 


\section{"Olhar o outro para olhar a si mesmo" - um diálogo entre arte e ciência na interpretação do cotidiano de Cabo Verde}

A aproximação entre ciência e arte sempre permeou os debates sobre os métodos para se interpretar o funcionamento do universo, descrever as diferentes sociedades e sua cultura, dentre outras atividades que permitem ao homem compreender a natureza e a si mesmo como agente em um processo constante de busca pelo conhecimento.

Em virtude de seus objetivos finais, a ciência e a arte oferecem-nos caminhos distintos para essa ação, permitindo-nos adotar diferentes perspectivas, construir racionalidades, aguçar subjetividades e refletir sobre o mundo, suas diversidades socioculturais, as diferentes interações entre os homens, representações sobre o outro e sobre si. Dessa forma, a ciência e a arte, para além de suas especificidades éticas, estéticas e epistemológicas, possuem pontos convergentes, encontrando na antropologia visual espaço profícuo para um diálogo entre imagem e palavra.

Exemplo dessa interlocução pode ser constatado na obra organizada por José Rogério Lopes, com textos resultantes do projeto de mobilidade acadêmica intitulado "Dinâmicas de gênero em Cabo Verde", o qual possibilitou a pesquisadores brasileiros e cabo-verdianos, por meio de fotografias de diferentes sujeitos, lugares e situações, desvelarem aspectos da realidade da realidade sociocultural da República de Cabo Verde.

As fotografias formam narrativas que envolvem um misto de poética e dados empíricos, promovendo reflexões sobre a vida, as rotinas, as práticas sociais, econômicas e culturais nas ilhas retratadas. Algumas imagens trazem pessoas em diferentes espaços e com seus modos de olhar, outras nos apresentam a geografia, a arquitetura, a moda, com suas cores e estilos, a timidez e a capacidade de mobilização, dentre outros momentos clicados por quem busca conhecer a dinâmica social pelo cotidiano.

Talvez por isso as belezas de Cabo Verde ocupam o segundo plano no olhar dos etnógrafos. Suas fotografias centram-se em situações de desigualdade, degradação ambiental, trabalho duro de mulheres e homens flagrados, algumas vezes, olhando para o horizonte, e provocam no leitor inquietações a respeito das significações do olhar do outro em seu próprio lugar. O que passa em seus pensamentos? Olham para as situações, para a paisagem ou para dentro de si? 
Essas indagações e outras mais emergem com a leitura do ensaio "Para onde olha essa gente? Registros de imagens de pessoas olhando o mar, mas também para as situações da realidade das ilhas de Cabo Verde", com fotografias produzidas por José Rogério Lopes e Marcelo Toledo.

As interpretações complementam-se com o ensaio "Para onde olha essa gente? Um olhar freelancer sobre Cabo Verde", escrito por José Rogério Lopes. Trata-se do olhar do etnógrafo sobre o campo e sua gente, em que se mesclam experiências do viajante e do pesquisador que reconhece ser preciso "olhar o outro para olhar a si mesmo" (p. 88).

São diferentes olhares, em diferentes direções e, em algumas narrativas, focados em parcelas específicas da população cabo-verdiana. Assim, no ensaio fotográfico "As vendedeiras de Cabo Verde: circulação de produtos, cores e mulheres no espaço público", Ângelo Pereira, José Rogério Lopes e Marcelo Toledo narram como as mulheres de Cabo Verde tornam-se protagonistas na economia local como vendedeiras de uma variedade de produtos, em, também diversos, lugares de comercialização.

A leitura é enriquecida pela análise de Celeste Forte em seu ensaio intitulado "As vendedeiras de Cabo Verde: informalidade e mulheres no espaço público de Cabo Verde". A autora nos mostra, ainda, que, apesar das dificuldades impostas pela legislação do poder municipal e do desejo de manutenção do sistema patriarcal machista, as mulheres vendedeiras são "rabidantes" (p. 104) e suas ações são símbolo da resistência feminina e instauram uma outra lógica relacional com o lugar, o trabalho e a cultura.

O tema da informalidade se expande para a ocupação de espaços de moradia, sendo registrados por José Rogério Lopes, Maristela Simon e Marcelo Toledo, no ensaio "Os sentidos do inacabado: os assentamentos informais e as moradas em Cabo Verde". O texto é composto por fotografias em que a arquitetura dos prédios e casas com cores e designs modernos contrapõem-se ao cinza, às escadarias, formatos e rusticidade de construções que se denunciam pertencentes a outro século. Nas imagens é possível diferenciar traços do rural do/no meio urbano, escassez de áreas verdes, que nos causam a sinestesia de secura, calor extremo e nos levam a subentender que, como arte, as fotografias despertam a sensibilidade de que o sentido de inacabado pode estar relacionado à desistência de um projeto de vida no lugar, denota o malogro do projeto de colonização, marca a ausência de políticas públicas de combate à desigualdade, 
ressalta as diferenças econômicas entre os continentes, revela que o espaço abandonado por um constitui-se moradia para outro, dentre outros significados que o conhecimento prévio do leitor é capaz de inferir.

Para esclarecer os plurissignificados do ensaio fotográfico, o texto "Cabo Verde na Praia de Santa Maria de Vitória: impressões sobre a cidade inacabada", escrito por Crisanto Barros, apresenta os contextos histórico, social e econômico do arquipélago, contribuindo para que se entenda por que ao olhar do outro, do forasteiro, "a Praia parece ser inacabada ou incompleta" (p. 124). O texto traz uma retrospectiva dos fatos que levaram à desagregação e decadência da economia local, nos séculos XVII e XVIII, chegando à construção de um projeto de recomposição econômica, pelo "branqueamento do capital" (p. 139), e pela ressignificação identitária, marcada pelo aproveitamento da diversidade cultural que colore os espaços, preenche o silêncio e encobre o som do mar daqueles que buscam no horizonte respostas para suas indagações.

Rodrigo Leistner, no ensaio "Rabelados do Espinho Branco: agenciamentos e processos de mediação cultural numa comunidade cabo-verdiana", analisa a inserção da pós-modernidade na vida cabo-verdiana e sua relação com a resistência do local aos apelos da modernidade, pela manutenção da arquitetura, materiais de construção e processos de manipulação de alimentos, dentre outras práticas sociais. As legendas das fotografias antecipam a informação de que a cultura local está se transformando em bem de consumo ao ser tratada como atrativo turístico. Leistner amplia a discussão sobre essa problemática no ensaio textual "Agenciamentos culturais em uma comunidade cabo-verdiana; impressões etnográficas sobre os Rabelados do Espinho Branco", em que busca "refletir sobre os significados que concernem à emergência das políticas de patrimonialização e implementação do turismo cultural na comunidade dos Rabelados do Espinho Branco" (p. 152). Suas análises projetam-se para as transformações advindas com o agenciamento cultural, exercido pelos próprios Rabelados em parceria com instituições públicas e privadas, sendo definido pelo autor como "propositivo" (p. 160), haja vista que as ações e a comercialização dos artefatos culturais são organizadas pela própria comunidade, sendo esta a maior beneficiária nesse processo.

Além da "qualidade sígnica, estética poética", os ensaios visuais apresentam "qualidade conteudística" própria das fotografias como trabalho antropológico (Saiman, 1994). Isso implica reconhecer que possibilitam diferentes 
interpretações, dependendo do olhar do leitor: 1) como arte, por possuírem a capacidade de lhe dar o livre arbítrio para preencher lacunas de sentidos; e 2) como procedimento de registro etnográfico, por apresentar uma cena sobre a qual deverá "desenvolver uma reflexão objetiva sobre como os indivíduos ou os grupos sociais representam, organizam e classificam as suas experiências e mantêm relações entre si" (Guran, 2002, p. 103).

Ler os ensaios visuais e escritos aqui comentados serve para que pesquisadores interessados em desenvolver estudos etnográficos percebam que as narrativas visuais possuem a mesma capacidade sígnica das escritas, possibilitando a apreensão e/ou interpretação da realidade, e, no caso da obra em tela, permitem ao leitor olhar para a história, economia, cultura e sociabilidades da vida em Cabo Verde pelo olhar e análise dos pesquisadores.

\section{Referências}

GURAN, M. Linguagem fotográfica e informação. 3. ed. Rio de Janeiro: Rio Fundo, 2002.

SAIMAN, E. G. Para que uma antropologia consiga tornar-se visual. In: FAUSTO NETO, A; BRAGA, J. L; PORTO, S. D. (Org.). Comunicação, cultura e política. Rio de Janeiro: Diadorim, 1994. v. 1, p. 33-46. 